\title{
Anticompetitive Entrenchment
}

\author{
Sean P. Sullivan ${ }^{*}$
}

\section{INTRODUCTION}

Frustration with the faltering state of competition pervades the news today. A recent article in the Wall Street Journal starts, "Across the ideological spectrum, the calls are growing louder: Washington must do more to rein in big business." It goes on to cite numerous industries in which only three or four competitors account for nearly all sales. ${ }^{2}$ An article in the Harvard Business Review states: "There's no question that most industries are becoming more concentrated." " A bill currently before the U.S. Senate declares that "unprecedented consolidation is reducing competition and threatens to place the American dream further out of reach for many consumers in the United States."4

Scholars are among the concerned commentators in this dialogue. Joseph Stiglitz, 2001 laureate of the Nobel Prize in economics, recently wrote that "[e]vidence of rising market power can be found almost anywhere" and that "[i]n sector after sector, from little things like cat food to big things like telecoms, cable providers, airlines, and technology platforms, a few firms now dominate $75-90 \%$ of the market, if not more." 5 Jonathan Baker, former director of the Federal Trade Commission's (FTC) Bureau of Economics, admits "[t]he U.S. economy has a 'market power'

\footnotetext{
* Associate Professor of Law, University of Iowa College of Law. Contact the author at seansullivan@uiowa.edu. I am grateful to Christopher Drahozal, Christopher Leslie, Daniel Sokol, Robert Tovsky, Spencer Weber Waller, and participants at the 2019 University of Florida Competition Conference, the 2019 University of Kansas Law Review Symposium on Antitrust Law \& Policy in the 21 st Century, and a faculty workshop at the University of Iowa for helpful comments and suggestions on earlier drafts of this paper.

1. Jacob M. Schlesinger et al., Tech Giants Google, Facebook and Amazon Intensify Antitrust Debate, WALl STREET J. (June 12, 2019, 6:00 PM), https://www.wsj.com/articles/tech-giants-google -facebook-and-amazon-intensify-antitrust-debate-11559966461 [https://perma.cc/6TUJ-V2UJ].

2. Id. (identifying four drug store chains, four airlines, four railroads, and several banking giants as controlling most of their respective industries).

3. David Wessel, Is Lack of Competition Strangling the U.S. Economy?, HARV. BuS. REV., Mar.-Apr. 2018, at 106, 107.

4. Consolidation Prevention and Competition Promotion Act of 2019, S. 307, 116th Cong. § 2(a)(9) (2019) (referred to the Committee on the Judiciary on Jan. 31, 2019).

5. Joseph E. Stiglitz, Commentary, Market Concentration Is Threatening the US Economy, PROJECT SYNDICATE (Mar. 11, 2019), https://www.project-syndicate.org/commentary/united-stateseconomy-rising-market-power-by-joseph-e-stiglitz-2019-03?barrier=accesspaylog [https://perma.cc /4D5J-WL2L].
} 
problem, notwithstanding our strong and extensive antitrust institutions." In economics, a vibrant literature has suddenly sprung up around exploring the rise in national industrial concentration measures and the simultaneous decline in various measures of competitive dynamics and productivity. ${ }^{7}$

Fingers point to antitrust enforcement failures as the source of these problems; antitrust law is accused of failing to keep concentration in check and to keep market power from expanding beyond control. Thus, a recent New York Times opinion blames enforcement "meekness" for rising consolidation. ${ }^{8}$ And an article in the Wall Street Journal asserts, "The time has come to reinvigorate antitrust enforcement." Many commentators agree with these sentiments and seek stronger antitrust policies to address them. ${ }^{10}$ But that's about where consensus ends.

As Carl Shapiro observes, not since the election of 1912 has antitrust played such a prominent role in politics and policy discussions. ${ }^{11}$ Some, like Senator Amy Klobuchar, would augment existing antitrust standards with thresholds tied to market structure or asset holdings. ${ }^{12}$ Others, like Senator Elizabeth Warren, would strengthen antitrust by sidestepping much of the modern framework - substituting political intervention and business regulation in its place. ${ }^{13}$ Others yet would reform antitrust by changing the focus of this area of law to account for a variety of "noneconomic" desiderata: the reduction of wealth disparities, advancement of labor interests, protection of small business, and

6. Jonathan B. Baker, Market Power in the U.S. Economy Today, WASH. CTR. FOR EQUITABLE GROWTH (Mar. 20, 2017), https://equitablegrowth.org/market-power-in-the-u-s-economy-today/ [https://perma.cc/LZH3-AXV6].

7. See infra notes $33-36,42-44,49-52$ and accompanying text.

8. David Leonhardt, Opinion, The Monopolization of America, N.Y. TIMES (Nov. 25, 2018), https://www.nytimes.com/2018/11/25/opinion/monopolies-in-the-us.html [https://perma.cc/ZPV9 -XSTM].

9. William A. Galston, The Perils of Corporate Concentration, WALl STREET J. (June 19, 2018, 7:06 PM), https://www.wsj.com/articles/the-perils-of-corporate-concentration-1529449577 [https:// perma.cc/FQC9-URS4].

10. See Christine S. Wilson, Comm'r, Fed. Trade Comm'n, Why We Should All Play by the Same Antitrust Rules, from Big Tech to Small Business, Address at the American Enterprise Institute 2 (May 4, 2019), https://www.ftc.gov/system/files/documents/public_statements/1527497/wilson remarks_aei_5-4-19.pdf [https://perma.cc/LGP8-TGEP] (commenting that "[m]any complain that [large high technology] firms wield too much power in the marketplace" and that "many policymakers have advanced what they characterize as simple fixes" to this problem).

11. Carl Shapiro, Antitrust in a Time of Populism, 61 INT'L J. INDUS. ORg. 714, 715 (2018).

12. See S. 307, 116th Cong. § 3 (2019) (Klobuchar sponsored the bill).

13. See, e.g., Elizabeth Warren, Here's How We Can Break Up Big Tech, Medium (Mar. 8, 2019), https://medium.com/@teamwarren/heres-how-we-can-break-up-big-tech-9ad9e0da324c [https://perma.cc/K5HZ-3T65]; Senator Elizabeth Warren, Reigniting Competition in the American Economy, Keynote Remarks at New America's Open Markets Program Event (June 29, 2016), https://www.warren.senate.gov/files/documents/2016-6-29_Warren_Antitrust_Speech.pdf [https:// perma.cc/FG5V-44CV] [hereinafter Warren, Reigniting Competition]. See also TIM WU, THE CURSE OF BigNESS: ANTITRUST IN THE NEW GILDED AGE 127-39 (2018) (suggesting expansive antitrust reforms). 
suppression of political influence, to name a few. ${ }^{14}$

There is room to debate the merits of these proposals. Klobuchar's proposals include legislation that could allow mergers of noncompeting firms to be enjoined on the dubious basis of the dollar value of firm assets. ${ }^{15}$ Warren's calls to break up big business recall some unsuccessful past efforts to achieve competitive gains by merely ordering the dissolution of large companies. ${ }^{16}$ And the suggested insertion of potentially contradictory social objectives into the antitrust framework conjures memories of the confused and indeterminate reasoning that resulted from attempts to pursue pluralistic objectives in the early days of antitrust. ${ }^{17}$ Of course, proponents of these reforms would rightly press that important benefits may flow from these strategies, and that the potential drawbacks are debatable.

What is beyond debate, however, is that all these reforms entail major changes for antitrust policy. That's basically the point. But before we overhaul a competition framework that has been decades in the making, we might first ask whether anything in the existing framework already provides a way of addressing the concentration and market power concerns at issue in the current reform movement. Indeed, this paper suggests that antitrust may today stand ready to address at least some of these concerns through its currently overlooked ability to intervene in mergers and acquisitions that serve to entrench market power in problematic markets. A brief digression on antitrust history will help explain what I mean.

In contrast to modern antitrust's almost exclusive focus on preventing accretions of market power, U.S. competition policy was, in the not too distant past, also willing to work in the reverse direction: using antitrust law - merger policy, in particular - to remedy ailing markets and facilitate

14. See Sean P. Sullivan, Antitrust Amorphisms, CPI ANTItrust Chron., Nov. 2019, at 1, 3, https://www.competitionpolicyinternational.com/antitrust-amorphisms/ [https://perma.cc/2CGQ -RC7G] (discussing several of the diverse social objectives identified with recent antitrust reform efforts); Herbert Hovenkamp, Whatever Did Happen to the Antitrust Movement?, 94 NOTRE DAME L. REV. 583, 583, 588-89 (2018) (similar).

15. S. 307, 116th Cong. § 3 (2019).

16. See, e.g., Warren, Reigniting Competition, supra note 13; Bell Atl. Corp. v. Twombly, 550 U.S. 544, 567-68 (2007) (observing, and treating as unremarkable, the failure of either initial divestiture or subsequent legislation to incentivize the components of the broken-up Bell System to compete with each other); $c f$. Herbert Hovenkamp \& Carl Shapiro, Horizontal Mergers, Market Structure, and Burdens of Proof, 127 YALE L.J. 1996, 2005 (2018) (commenting that "[e]fforts to proactively deconcentrate industries can easily be counterproductive" if they result in the most efficient firms being broken up, prevent scale economies from forming, or chill efforts to compete because success would only mean forced divestiture); D. Daniel Sokol, Antitrust's Curse of Bigness Problem, 118 MICH. L. REV. (forthcoming 2020) (reviewing WU, supra note 13, and critiquing the administrability of attempts to intervene against bigness on populist grounds).

17. Cf. Hovenkamp, supra note 14 , at 585 (commenting that many populist goals are "unmeasurable and fundamentally inconsistent, although with their contradictions rarely exposed"). 
competition where it was seen to be lacking. ${ }^{18}$ In short, the strategy was to prevent the entrenchment of already-existing concentration and market power by taking an especially restrictive position on mergers in already problematic markets. This approach featured prominently in important merger cases of the 1960s and 70s but fell out of fashion during the evolution of the modern antitrust framework. ${ }^{19}$ This article considers how it might be brought back, exploring how renewed opposition to anticompetitive entrenchment could address concentration and market power concerns without requiring massive changes to current antitrust policy.

To summarize the argument, where careful analysis suggests that a relevant market is highly concentrated, and that competitive performance is diminished as a result, it is within the scope of existing merger law to foreclose mergers and acquisitions in this market even without specific proof that something like price elevation would result therefrom. The normative basis for such an injunction is not the usual claim that the merger or acquisition would make things worse in the relevant market. Rather, the basis for injunction is concern with current competitive conditions, and a corresponding public interest in preserving opportunities for the grind of competitive frictions to make things better in the future. ${ }^{20}$ The concern is, in a nutshell, about the entrenchment of an already anticompetitive status quo.

What I propose as a renewed theory of anticompetitive entrenchment traces to seminal cases in merger law and shares features with modern modes of antitrust analysis. It relates to the antitrust analysis of potential competition cases, but is distinct from and less controversial than potential competition doctrine. ${ }^{21}$ It relates to concerns about the exercise of monopoly power, but is more focused, effective, and administrable than other statutory bases for addressing these concerns. ${ }^{22}$ It relates to forwardlooking prediction of competitive effects in modern merger analysis, but requires less specificity in the prediction of future competition where competitive conditions are already bad. ${ }^{23}$ Finally, it relates to what

18. See infra Section III.A.

19. See infra notes $76-80$ and accompanying text.

20. See infra Section III.B.

21. See Philip E. AREEda \& Herbert HovenKamp, 5 Antitrust LaW ch. 11B-1, at 54-79 (4th ed. 2016).

22. See William E. Kovacic \& Marc Winerman, Competition Policy and the Application of Section 5 of the Federal Trade Commission Act, 76 ANTITRUST L.J. 929, 929, 940-43 (2010) (noting judicial narrowing of the range of conduct condemned by Section 2 and raising cautions about the use of Section 5 of the FTC Act as a means of addressing single-firm conduct).

23. See U.S. Dep'T of Justice \& Fed. Trade Comm'N, Horizontal Merger Guidelines $\S \S$ 6-7 (2010), https://www.justice.gov/sites/default/files/atr/legacy/2010/08/19/hmg-2010.pdf [https:// 
Herbert Hovenkamp has referred to as "prophylactic" merger policy, suggesting an important extension of the prophylactic potential of merger control. ${ }^{24}$ It is a powerful tool in need of careful application, but it is not a new approach to antitrust. Rather, it is "old antitrust," updated to fit the modern framework and to address the concerns of the present day.

The remainder of this article proceeds as follows. In Part II, I collect evidence on the state of concentration and market power. While the evidence of a problem may not impress every reader, there is no basis for the outright rejection of popular concerns about rising concentration and market power. In short, a reasonable concern has been raised, and antitrust should supply an answer. In Part III, I explain how a revitalized concept of anticompetitive entrenchment - informed by the principles of modern economic analysis - could help to address this concern. I illustrate the potential of this entrenchment approach using two examples. First, I show in Part IV how a theory of anticompetitive entrenchment could help to address tacit collusion in a tight oligopoly. Second, I show in Part V how this approach could apply to a dominant firm in a market protected by scale or network effects. Throughout Parts III to V, discussion considers possible objections to this entrenchment theory and what it can realistically achieve.

\section{IS THERE A MARKET CONCENTRATION PROBLEM?}

Notwithstanding the sweeping claims of some commentators, it is actually quite difficult to identify broad trends in market concentration and market power. Market definition, as the term is used in antitrust, has little to do with lay concepts of industries or lines of commerce, which makes national and even "industrial" concentration data imperfect proxies for the subject of concern. ${ }^{25}$ Moreover, because market power can arise from many sources, identifying the market power that derives specifically from market concentration can be a difficult task.

Subject to these disclaimers, however, available evidence appears to support three analogs of now-popular claims. First, seller concentration appears to have been rising in recent decades. Second, market power appears to have risen as well, particularly in the last decade. Third, there

perma.cc/5JBB-STKV] [hereinafter 2010 HORIZONTAL MERGER GUIDELINES] (describing forwardlooking merger analysis, mainly concerned with predicting future competitive harm); Gregory J. Werden \& Kristen C. Limarzi, Forward-Looking Merger Analysis and the Superfluous Potential Competition Doctrine, 77 ANTITRUST L.J. 109, 110 (2010) (arguing that potential competition concerns can be addressed in the usual Section 7 analysis, without any special doctrine or approach).

24. See generally Herbert Hovenkamp, Prophylactic Merger Policy, 70 Hastings L.J. 45 (2018) (discussing the prophylactic reach of merger policy under the Clayton Act).

25. See David Glasner \& Sean P. Sullivan, The Logic of Market Definition, 83 ANTITRUST L.J. § I.A (forthcoming 2020). 
is currently no explanation of the latter trend that can obviously eliminate rising concentration as a plausible contributor to rising market power in at least some markets. The following discussion walks through each of these claims in turn.

\section{A. Seller Concentration Seems to Be Rising}

Concerns about seller concentration reflect the everyday observations of consumers. Familiar examples illustrate the recent growth in concentration in certain bands of commerce. The number of major airlines has decreased from as many as nine at the turn of the century to only four today. ${ }^{26}$ There are fewer yet on many regional flight paths. ${ }^{27}$ The number of major brewers has declined to the point where the vast majority of U.S. beer sales now trace to only two companies. ${ }^{28}$ In many cities, hospital service providers long ago reached worrying concentration levels, ${ }^{29}$ and recent data suggest that primary care providers may now be following suit. ${ }^{30}$ This is to say nothing of the small number of tech giants like Google, Amazon, and Microsoft that dominate so many consumer-facing technologies. While the examples could easily go on, the plural of anecdote is not data, and a careful review of the evidence would ask whether these individual cases are reflected in broader national trends.

Subject to the imprecision of treating things like NAICS industry classifications as antitrust relevant markets, ${ }^{31}$ the answer appears to be "Yes." Looking at Economic Census data, for example, Sam Peltzman reports that concentration in manufacturing industries, which had been

26. See, e.g., BAKER, supra note 6, at 5 ("A number of major industries, including airlines ... have become substantially more concentrated over recent decades. The number of major U.S. airlines, for example, including regional and low-cost carriers, has declined after multiple mergers, from nine in 2005 to four today."). Concentration raises special concerns when it is accompanied by substantial horizontal shareholding. See generally Einer Elhauge, Horizontal Shareholding, 129 HARV. L. REV. 1267 (2016) (providing a powerful demonstration of how horizontal shareholding can exacerbate competitive concerns in concentrated markets).

27. See, e.g., Wessel, supra note 3, at 108 ("Although competition is stiff on the most heavily traveled air routes, $97 \%$ of routes between pairs of cities have so few competitors that standard antitrust metrics would deem them 'highly concentrated."').

28. See, e.g., Baker, supra note 6, at 5 ("Anheuser-Busch InBev SA/NV and Molson Coors Brewing Co. account for nearly three-fourths of the beer sold in the United States ...."); Wessel, supra note 3, at 108 ("Despite the proliferation of craft breweries, four brewers hold nearly $90 \%$ of the U.S. beer market.").

29. See, e.g., Brent D. Fulton, Health Care Market Concentration Trends in the United States: Evidence and Policy Responses, 36 HEALTH AFF. 1530, 1530-34 (2017) (noting that the mean HHI in MSA-defined hospital markets is now in excess of 5,500).

30. Id. at 1533-35 (noting that the average HHI in primary care physician markets increased by nearly twenty-nine percent from 2010 to 2016).

31. See generally Glasner \& Sullivan, supra note 25 (discussing the difference between "industry" lines and the boundaries of antitrust relevant markets). 
roughly stable between 1963 and 1982, ${ }^{32}$ took a steady upward turn under the modern antitrust regime, with increases in concentration two to four times more likely than decreases in the decades following $1982 .{ }^{33}$ Peltzman summarizes this finding with the ominous conclusion that "[a]s soon as the ink was drying on the first Merger Guidelines, concentration began increasing in U.S. manufacturing." "34 Broadly similar conclusions are reported outside of manufacturing. Using the merged CRSP/Compustat database, Grullon, Larkin, and Michaely report that concentration, as measured by HHI, increased in about $80 \%$ of industries from 1997 to 2014, with a median increase of about 40\% and a mean increase of about $90 \%{ }^{35}$ These national averages mask significant heterogeneity in industry-level data, ${ }^{36}$ but are directionally consistent with the premise that seller concentration is rising in many sectors of the economy.

\section{B. Market Power Seems to Be Rising, Too}

Of course, evidence of growing seller concentration is not itself a bad thing. Markets may become concentrated for benign reasons, such as technological innovation and the emergence of new economies of scale or fixed costs of production. The worry is that growing concentration is enhancing market power. Thus, a threshold question is whether market power is growing as well.

Again, everyday experience provides stark examples. Nobody who has flown on domestic airlines in recent years can seriously doubt the exercise of market power by these companies. ${ }^{37}$ Similar, but less personal, evidence of rising market power can be found in economic research.

32. Sam Peltzman, Industrial Concentration Under the Rule of Reason, 57 J. L. \& ECON. S101, S105-06 (2014).

33. Id. at $\mathrm{S} 112-13$.

34. Id. at $\mathrm{S} 117-18$.

35. Gustavo Grullon et al., Are U.S. Industries Becoming More Concentrated?, 23 REV. FIN. 697, 704 (2019). There are reasons to be skeptical about the use of Compustat data in measuring concentration. See, e.g., Ashiq Ali et al., The Limitations of Industry Concentration Measures Constructed with Compustat Data: Implications for Finance Research, 22 REV. FIN. STUD. 3839, 3840 (2009) (discussing the limitations of Computstat data as a basis for measuring industry concentration, including its omission of private firms). Grullon et al. do, however, report similar findings when private firms are included in model specifications. See Grullon et al., supra, at 699.

36. See, e.g., Peltzman, supra note 32, at S112-15 (noting significant differences in trends between consumer-good and producer-good manufacturing industries); Leila Davis \& Özgür Orhangazi, Competition and Monopoly in the U.S. Economy: What Do Industrial Concentration Data Tell? 23 (Political Econ. Research Inst. Working Paper Series, Paper No. 492, 2019) (identifying particular concentration growth in retail and information services industries).

37. Cf. Thomas Philippon, The U.S. Only Pretends to Have Free Markets, The AtLantic (Oct. 29, 2019), https://www.theatlantic.com/ideas/archive/2019/10/europe-not-america-home-free-market /600859/ [https://perma.cc/CR97-QBXR] ("[U.S. airline] profits per passenger mile are now about twice as high as in Europe, where low-cost airlines compete aggressively with incumbents."). 
Economists studying the now highly concentrated beer industry, for example, report what appears to be patterns of collusive pricing among the major brewers. ${ }^{38}$ Likewise, economists studying the now highly concentrated airline industry report what appears to be collusive pricing among the major airlines. ${ }^{39}$ And while economists studying the growth in hospital concentration look for efficiency and service benefits resulting from past mergers, they often uncover rising prices and stagnant or declining service quality instead. ${ }^{40}$

Again, these observations are consistent with trends in national data. By several accounts, growth in national estimates of market power has roughly paralleled that in concentration over recent decades. A recent study by De Loecker, Eeckhout, and Unger reports that-after a long period of stability - average profits began a steep rise in the 1980s, which has continued to this day. ${ }^{41}$ The study observes that margins relative to marginal costs increased from about $21 \%$ in 1980 to about $61 \%$ in $2016 .{ }^{42}$ Using BEA data on corporate profits, Shapiro notes a similar increase in profits as a percent of GDP over the past 30 years. ${ }^{43}$ Absent a better explanation, Shapiro interprets this as a sign that "U.S. corporations really are systematically earning far higher profits than they were 25 or 30 years ago." 44

\section{Rising Concentration Seems to Be Creating Market Power}

Finally, having noted evidence of both growing seller concentration and growing market power, a careful researcher should ask whether the former is causing the latter. Causal connections are notoriously difficult to prove in economics, and this is no exception. With that said, the evidence is at least consistent with the inference that growing

38. Nathan H. Miller \& Matthew C. Weinberg, Understanding the Price Effects of the MillerCoors Joint Venture, 85 ECONOMETRICA 1763, 1788-89 (2017).

39. Federico Ciliberto et al., Collusive Pricing Patterns in the US Airline Industry, 62 INT'L J. INDUS. ORG. 136, 137-38 (2019); see also Kevin Mitchell, Spoiler Alert - Airline Admits Its AntiCompetitive Ways, INSIDE SOURCES (July 9, 2018), https://www.insidesources.com/spoiler-alert -airline-admits-anti-competitive-ways/ [https://perma.cc/2HLG-3BDD] (providing a popular press account of anticompetitive behavior among major airlines).

40. See Martin Gaynor et al., The Industrial Organization of Health-Care Markets, 53 J. ECON. LiterATURE 235, 247-51 (2015); Martin Gaynor \& Robert Town, The Impact of Hospital Consolidation, SYNTHESIS PROJECT (2012), https://www.rwjf.org/en/library/research/2012/06/the -impact-of-hospital-consolidation.html [https://perma.cc/KN87-L6N4].

41. Jan De Loecker et al., The Rise of Market Power and the Macroeconomic Implications, 135 Q.J. ECON. 561, 561 (2020).

42. Id. at 562. The increase is not stable over the entire period. Margins increase most during the $80 \mathrm{~s}, 90 \mathrm{~s}$, and after 2008. Id. at 562-63.

43. Shapiro, supra note 11, at 732 (illustrating about a $50 \%$ increase in this figure since the 1980s).

44. Id. at $732-33$. 
concentration is contributing to growing market power in some markets. This is true at both the micro and macro levels.

At the micro level of antitrust relevant markets, one place to seek evidence of a causal connection between changes in market concentration and market power is through retrospective analysis of consummated mergers. Since mergers do nothing but alter the structure of markets in a way that increases concentration, changes in behavior before and after a merger provide one way of measuring how recent increases in market concentration have tended to affect market power. ${ }^{45}$

Surveys of merger retrospectives provide clear evidence that the kind of mergers consummated under modern merger policy have indeed enhanced market power in some-but not all - cases. For example, in a detailed review of reliable retrospective studies covering some forty-two mergers, John Kwoka reports post-merger price increases in thirty-four mergers, with post-merger price decreases in the remaining eight. ${ }^{46}$ For the roughly $60 \%$ of products with price increases in these studies, Kwoka estimates a nearly $9 \%$ average post-merger price increase. ${ }^{47}$ Similar results are reported by Orley Ashenfelter, Daniel Hosken, and Matthew Weinberg, who surveyed forty-nine merger retrospectives to report postmerger price increases in thirty-six of these studies, with price decreases found in thirteen studies and with price stability found in thirteen studies as well. ${ }^{48}$

Trends in the national data support a similar conclusion - though, again, the evidence is equivocal. While market concentration and market power seem to have grown in rough proportion over recent decades, the correlation between concentration and market power is imperfect. ${ }^{49}$ Leila Davis and Özgür Orhangazi summarize the data in terms similar to the merger retrospective surveys: in some industries, an increase in

45. This statement refers to horizontal mergers. The relationship between market concentration and vertical mergers is more complicated. $C f$. Jonathan B. Baker, Nancy L. Rose, Steven C. Salop \& Fiona Scott Morton, Five Principles for Vertical Merger Enforcement Policy, 33 ANTITRUST 12, 16 (2019) (noting, among other things, that "coordinated effects from eliminating an upstream maverick would not require the downstream market to be concentrated").

46. John KWOKa, Mergers, Merger Control, AND REMEdies: A Retrospective ANALysis OF U.S. POLICY 113 (2015). Important to understanding these figures, the antitrust agencies challenged only 13 of the 34 mergers in which price increases were subsequently observed. Id.

47. Id. at 94 .

48. Orley Ashenfelter et al., Did Robert Bork Understate the Competitive Impact of Mergers? Evidence from Consummated Mergers, 57 J.L. \& ECON. S67, S78-S79 (2014). Studies covering multiple mergers result in a sum that exceeds 49 because it is possible to find evidence of both price increases and price decreases when assessing multiple transactions. Id. at S78 n.23.

49. See, e.g., Ryan A. Decker, Big Is Beautiful: Debunking the Myth of Small Business, by Robert D. Atkinson and Michael Lind, 54 BuS. ECON. 145, 146 (2019) (book review) ("De Loecker and Eechout find markups have risen most in sectors in which concentration has risen least ...."); Davis \& Orhangazi, supra note 36 , at 19-20 (noting that profit rates are not uniformly higher for higher concentration industries). 
concentration corresponds with an increase in market power, while in other industries it does not. ${ }^{50}$ But despite the existence of confounding sources of market power and heterogeneity in the national data, ${ }^{51}$ no recent study has yet to explain rising U.S. market power in terms that exclude market concentration as a potentially significant contributor. ${ }^{52}$ National data thus lend qualified support to the proposition that growing concentration may be enhancing market power in at least some markets.

To summarize, available data are consistent with aspects of popular concerns about concentration and market power problems. Both seller concentration and market power appear to have risen in at least some segments of the economy over the past thirty years. The rise in market power is a complicated and inadequately understood phenomenon, but is plausibly driven, in part, by rising market concentration. While these data certainly leave room for alternative interpretations, the remainder of this article takes seriously popular concerns, and assumes that market concentration is today resulting in the persistent exercise of market power in at least some relevant markets. The question is what antitrust can do about it.

\section{HOW OPPOSING ANTICOMPETITIVE ENTRENCHMENT COULD ADDRESS MARKET CONCENTRATION PROBLEMS}

As discussed earlier, many of the recent proposals for antitrust reform involve political intervention or large-scale changes to the framework as ways of addressing concentration and market power problems. ${ }^{53}$ While these are certainly feasible options, a more deliberate approach might start by asking whether anything in the existing framework already provides a basis for addressing these concerns. The following discussion identifies a

50. Davis \& Orhangazi, supra note 36, at 19; cf. Steven Berry et al., Do Increasing Markups Matter? Lessons from Empirical Industrial Organization, 33 J. ECON. PERSP. 44, 44-48 (2019) (commenting on both conceptual and practical difficulties in attempts to assess concentration-markup relationships across heterogeneous industries).

51. See, e.g., David Autor et al., The Fall of the Labor Share and the Rise of Superstar Firms, 135 Q.J. ECON. 645, 649-56, 673 (2020) (modeling how technological change could result in a "winner takes most" feature that leads to both higher market concentration and higher profits); ChangTai Hsieh \& Esteban Rossi-Hansberg, The Industrial Revolution in Services 2-4 (Nat'l Bureau of Econ. Research, Working Paper No. 25968, 2019) (attributing growing seller concentration to the adoption of new fixed-cost technologies).

52. See Matias Covarrubias et al., From Good to Bad Concentration? U.S. Industries Over the Past 30 Years 2-6 (Nat'l Bureau of Econ. Research, Working Paper No. 25983, 2019) (reviewing alternative interpretations of the available macro data in concluding that a sharp increase in profits in the 2000s is best explained by competition barriers); see also Shapiro, supra note 11, at 733 ("High and persistent profits for any one firm are easy to explain, in theory, based on that firm being more efficient than its rivals. But if high and persistent profits are widespread, any economist will naturally ask why competitive forces are not eroding those supra-normal profits.").

53. See supra notes $12-17$ and accompanying text. 
string of cases in the 1960s and 70s that envisioned merger enforcement as a remedial tool for responding to excessive concentration and lax competition. It then considers how this approach might be updated to reflect modern economic analysis ${ }^{54}$ and reintroduced to antitrust practice to help combat market concentration and market power problems today.

\section{A. Merger Enforcement as Remedy Rather Than Prevention}

The preventative focus of modern merger enforcement demands evidence that fairly specific anticompetitive injuries will result from a merger or acquisition before remedies will be contemplated. This expectation is apparent in commentary implying that merger analysis should only act to prevent enhancements of market power. ${ }^{55}$ It is similarly apparent in demands for specific proof of how a merger will tend to enhance market power. ${ }^{56}$ It is apparent in the typical approach taken to market definition in merger cases. ${ }^{57}$ And it is apparent in expectations that potential competition cases should be limited to only those circumstances in which specific predictions of forgone competition can be articulated. ${ }^{58}$

But merger enforcement has not always been so singularly focused on prevention and the enhancement to market power. In the 1960s, a string

54. Antitrust law exhibits remarkable flexibility in its ability to adapt to and incorporate changes in economic thinking and interpretation. See Kimble v. Marvel Entm't, LLC, 135 S. Ct. 2401, 241213 (2015) (commenting that the Court "has viewed stare decisis as having less-than-usual force in cases involving the Sherman Act" and has "therefore felt relatively free to revise . . legal analysis as economic understanding evolves"); see also D. Daniel Sokol, Rethinking the Efficiency of the Common Law, 95 NOTRE DAME L. REV. 795, 829-32 (2019) (discussing the efficiency-increasing evolution of antitrust law under a singular focus on consumer welfare).

55. See, e.g., Patrick Massey, Market Definition and Market Power in Competition Analysis: Some Practical Issues, 31 ECON. \& SOC. REV. 309, 323 (2000) ("In assessing the competitive impact of a merger the crucial issue is not whether one of the merging parties already enjoys a degree of market power, but whether, as a result of the merger, the degree of market power would increase."); Gregory J. Werden, Market Delineation and the Justice Department's Merger Guidelines, 1983 DUKE L.J. 514, 525 (distinguishing merger review from analysis under Section 2 of the Sherman Act, stating that "the ultimate question [in merger analysis] is whether a merger would create or enhance market power").

56. See, e.g., 2010 HorizOnTAL MERGER Guidelines, supra note 23, §§ 6-7 (identifying the evidence of specific competitive effects that the antitrust agencies seek in review of mergers); Peter C. Carstensen, The Philadelphia National Bank Presumption: Merger Analysis in an Unpredictable World, 80 ANTITRUST L.J. 219, 238 (2015) (critiquing the demand for "a specific, identifiable likely effect" that became commonplace between the 1982 and 1992 Merger Guidelines).

57. See, e.g., John B. Kirkwood, Market Power and Antitrust Enforcement, 98 B.U. L. REV. 1169 , 1194 (2018) (commenting that the dominant approach to market definition in merger cases "asks whether the defendant could increase price above [the prevailing] level" and that this, like "a great deal of antitrust enforcement," reflects an interest in identifying "conduct that threatens to raise price above the current level").

58. See, e.g., Werden \& Limarzi, supra note 23, at 136-37 (“[T]he 'reasonable probability' test is not satisfied by proof that the acquiring firm, but for a proposed merger, someday might have entered on its own .... [A]s a general rule, the firm would have to be far along a well-defined path toward entry."). 
of merger cases pursued a different objective: enjoining mergers not because they posed a specific threat to current competitive conductions, but as a way of fostering opportunities for future competition. ${ }^{59}$ This approach did not seek specific proof that a merger would make things worse. It focused instead on whether obstruction of a merger might help to remedy an already anticompetitive status quo.

The seminal statement of this alternative approach to merger enforcement is provided by the Supreme Court in a well-known footnote to the majority opinion in United States v. Philadelphia National Bank:

It is no answer that, among the three presently largest firms ... there will be no increase in concentration. If this argument were valid, then once a market had become unduly concentrated, further concentration would be legally privileged. On the contrary, if concentration is already great, the importance of preventing even slight increases in concentration and so preserving the possibility of eventual deconcentration is correspondingly great. ${ }^{60}$

This appears to contemplate that upon finding a relevant market excessively concentrated, a court might adopt a strict enforcement posture as a means of protecting existing opportunities for future competition. While Philadelphia National Bank's discussion of this idea was mainly limited to this footnote, the Court returned to the strategy only a year later in United States v. Aluminum Co. of America (Rome Cable). ${ }^{61}$

The transaction at issue in Rome Cable was an acquisition, by the infamous ALCOA company, of a small rival in the production of aluminum cable. ${ }^{62}$ In contrast to ALCOA, Rome had only about a $1.3 \%$ market share at the time of its acquisition. ${ }^{63}$ In finding this merger to violate Section 7 of the Clayton Act, the Court followed the framework it had telegraphed in Philadelphia National Bank. ${ }^{64}$ It first emphasized the poor competitive condition of the market at the time of acquisition, and then directed attention to the potential for future competition created by the independence of small companies like Rome: ${ }^{65}$

It would seem that the situation in the aluminum industry may be oligopolistic. As that condition develops, the greater is the likelihood

59. See infra notes $60-71$.

60. United States v. Phila. Nat'1 Bank, 374 U.S. 321, 365 n.42 (1963) (emphasis added).

61. 377 U.S. 271, 279 (1964).

62. Id. at 272 .

63. Id. at $272-74$.

64. Id. at 279 ("The proposition on which the present case turns was stated in [Philadelphia National Bank] ...." (quoting Phila. Nat'l Bank, 374 U.S at 365 n.42)).

65. Id. at $280-81$. 
that parallel policies of mutual advantage, not competition, will emerge. That tendency may well be thwarted by the presence of small but significant competitors. ${ }^{66}$

A narrow parsing might read Rome's role in preventing competitive deterioration (not fostering future competition) as the Court's key concern, but the distinction is ultimately hollow. First, the prevention of further competitive deterioration is itself a form of remedy in the context of a downward trending status quo. Second, given its miniscule size, the only way that Rome could either have disrupted or reversed a trend toward soft oligopolistic competition lay in its potential for growth if preserved as an independent competitor.

A noteworthy feature of the Court's approach to merger enforcement in these cases is that it did not involve the level of predictive specificity expected in merger enforcement today. This is particularly clear in United States v. Continental Can Co., a case in which the Court applied the same approach in its review of a large metal can manufacturer's acquisition of a glass container manufacturer in a relevant market defined to include both metal and glass containers. ${ }^{67}$ Responding to evidence of limited competition between these firms at the time of the merger, the Court emphasized that anticompetitive effects of a merger embrace "not only [] the static competitive situation but also the dynamic long-run potential" of the merger to foreclose future competition. ${ }^{68}$ Yet the majority made little effort to prove or even predict what exactly this future competition would entail. ${ }^{69}$ The opinion rested instead on the general thesis that competition was inevitable - perhaps especially so in an underperforming market - if independent competitors were forced to square off against each other over a long enough horizon. ${ }^{70}$

Finally, another noteworthy feature of this approach to merger enforcement is its pursuit of remedies for current competitive problems as the justification for intervention. This remedial focus is strongly suggested in the cases discussed above, especially Philadelphia National Bank and its interest in using merger enforcement to bolster "the possibility of eventual deconcentration." ${ }^{71}$ It is explicit in the Second Circuit opinion in

66. Id. at 280 .

67. 378 U.S. 441, 457-62 (1964). Whether this case would be better analyzed as a potential competition fact pattern is irrelevant for present purposes. See Werden \& Limarzi, supra note 23, at 111 (denying any helpful distinction between potential competition cases and standard forwardlooking merger analysis).

68. Cont'l Can, 378 U.S. at 464-66.

69. Id. at 465 (noting, but not specifically predicting, various possible ways that the elimination of current or potential competition between the merging firms might foreclose future competition).

70. See id.

71. See United States v. Phila. Nat'l Bank, 374 U.S. 321, 365 n.42 (1963). 
Stanley Works v. FTC, upholding injunction of the acquisition of a small cabinet maker (with about a $1 \%$ market share) by the industry leader in an otherwise oligopolistic market. ${ }^{72}$ Adopting the reasoning of earlier Supreme Court cases, the Second Circuit followed the now familiar pattern: focusing first on poor competitive conditions, and then on the potential for future competition as its justification for intervention. ${ }^{73}$ It went further, however, in specifically identifying the remedial project behind this approach:

Section 7's incipiency standard, which "requires not merely an appraisal of the immediate impact of the merger upon competition, but a prediction of its impact upon competitive conditions in the future", provides preventive as well as remedial therapy for an ailing industry; surely its salutary medicines need not be withheld until the diagnosis reads "terminal." 74

The implication of this and earlier Supreme Court cases is that antitrust may prohibit mergers and acquisitions not only for the nowstandard purpose of preventing an enhancement of market power. Merger enforcement may also function as "remedial therapy" for addressing existing problems in a relevant market. ${ }^{75}$

Of course, the antitrust policy of the 1960s and 70s differed in fundamental ways from the modern framework. Many opinions of this era were concerned with concentration qua concentration, whereas today market concentration is relevant only as one of several potential determinants of market power. ${ }^{76}$ These opinions also labored under definitions of dominance and oligopoly that would not begin to satisfy the modern meaning of these terms. ${ }^{77}$ But the fundamental approach to merger enforcement envisioned in the cases discussed in this section transcends technical implementation details. The next section considers how the approach might be updated and reintroduced to the modern framework.

72. 469 F.2d 498, 499-501 (2d Cir. 1972).

73. Id. at 508 (" $[\mathrm{T}]$ hough a market may be concentrated, forces may operate so as to maintain some level of competition and thus preserve the possibility of eventual deconcentration. That is why the continued independence of companies with relatively small market shares is so crucial to the health and vitality of a market threatening to become oligopolistic.").

74. Id. at 505 (emphasis added) (quoting Phila. Nat'l Bank, 374 U.S. at 362).

75. See id.

76. Cf. Cristofer Esty Lord, Entrenchment Challenges to Conglomerate Mergers, 60 WASH. U. L.Q. 537, 537-38 (1982) (“A review of the legislative history of the Celler-Kefauver Act reveals that Congress was deeply concerned about increased market concentration."); Hovenkamp, supra note 14, at 624-26 (discussing the limited relevance of "industrial concentration" in modern antitrust analysis).

77. Cf. Lord, supra note 76, at 543-50 (describing concerns with conglomerate "entrenchment" in largely protectionist terms). 


\section{B. Reintroducing the Theory of Anticompetitive Entrenchment}

Though it may not have seemed so at the time they were penned, the previously discussed opinions introduced antitrust to a distinct approach to merger enforcement. The immediate focus of this approach was on forestalling the entrenchment of competitive problems, but the deeper objective was remedial in nature. Where competitive problems were already apparent at the time of a merger or acquisition, a strict and restrictive enforcement posture was seen as a way of preserving all possible opportunities for competitive friction and independent interaction in service of the more fundamental objective of trying to remedy existing competitive problems in this market.

While hints and echoes of this approach still linger in modern merger policy, ${ }^{78}$ full-throated concern with the entrenchment of market power is simply missing from the current framework. Neglect of the theory has been so complete that the cases advancing the entrenchment approach have become dated and exhibit linguistic and logical gulfs when compared with modern merger cases. The disconnects from modern practice are superficial, though, and can be resolved with only modest tweaking. As a bridge between the past and present, I suggest the following working statement of a modern entrenchment theory of merger enforcement:

Where a relevant market is unduly concentrated at the time of a merger, and where this concentrated market structure appears to be facilitating the exercise of market power, a merger of competitors may be enjoined even in the absence of specific proof that it would result in a price increase, output decrease, or the like. The purpose of this injunction is not to preserve the outcomes of current competition, but instead to protect the opportunity for existing competitive frictions eventually to

78. The introduction to the current Merger Guidelines declares the overarching principle that "mergers should not be permitted to create, enhance, or entrench market power or to facilitate its exercise.” 2010 Horizontal MERGER GUIDELINES, supra note 23, § 1 (emphasis added). While the Guidelines make few explicit references to entrenchment after this introduction, concerns about preserving opportunities for future competition appear throughout the document. E.g., id. § 2.1.4 (describing potential unilateral injury where "the merging firms ... likely will become absent the merger, substantial head-to-head competitors"); $i d$. $\$ 2.1 .5$ (noting potential coordinated injury where "one of the merging firms has a strong incumbency position and the other merging firm threatens to disrupt market conditions ... their merger can involve the loss of actual or potential competition"); id. $\S 4.1 .2$ (substituting "anticipated future prices as the benchmark for the [HMT] test" where "prices are likely to change absent the merger, e.g., because of innovation or entry"); id. $\S 6.4$ (noting the possible elimination of "innovation competition" where one of the merging firms would likely "develop new products in the future that would capture substantial revenues from the other merging firm”); accord Am. Needle, Inc. v. Nat'l Football League, 560 U.S. 183, 195 (2010) (emphasizing, in the context of a Section 1 case, the importance of "separate economic actors pursuing separate economic interests," because agreements limiting the independence of such competitors " "deprive[] the marketplace of independent centers of desionmaking'... and thus of actual or potential competition [between these firms]" (quoting Copperweld Corp. v. Indep. Tube Corp., 467 U.S. 752, $769(1984)))$ 
improve outcomes in this market. ${ }^{79}$

Importantly, a modern implementation of this entrenchment approach would be subject to other developments in merger policy, including the evolution of a defense recognizing certain merger-specific efficiencies and the modern approach to analyzing impending failure and exiting-asset considerations. ${ }^{80}$

For addressing concerns about current market concentration and market power problems, this entrenchment theory offers an appealing alternative to more heavy-handed proposals like active deconcentration or low-level regulation of businesses. For example, the entrenchment approach requires far less government intervention in the function of markets. ${ }^{81}$ It continues the settled practice of preferring organic competition over regulation, whenever the former can possibly act to protect consumer interests. And it has the administrability advantage of nesting within the already established framework of modern antitrust analysis. ${ }^{82}$ But reintegrating the entrenchment theory into merger enforcement would still be a change for modern merger policy, and like most changes, there would be costs to bear and challenges to overcome.

Among the costs, reintroducing the entrenchment approach to merger enforcement would compel litigants and courts to grapple with some substantial, and even novel, proof problems. First, and most obviously, this approach puts heavy weight on the proper definition of relevant markets and the accurate identification of market structure within a relevant market. ${ }^{83}$ Market definition and proof of undue concentration in a relevant market are already fraught aspects of merger litigation, ${ }^{84}$ and

79. "Competitive frictions" contemplate all the ways that dynamic competition may eventually destabilize and erode existing market power. Examples include exogenous cost, demand, and technology shocks as transformed by imperfect information about market conditions and the behavior and strategies of rival firms into changes in those behaviors and strategies.

80. See 2010 Horizontal Merger Guidelines, supra note 23, $\S \S 10-11$ (describing the Agencies' consideration of efficiencies and exiting-assets defenses); see also id. $\S \S 5.1,5.2,9$ (providing a more nuanced treatment of entry than existed in earlier entrenchment cases).

81. Cf. Stephen Martin, Industrial ORganization in CONTEXt 697 (2010) (noting that one of the few obvious remedies for tacit collusion would be regulation, but observing that "regulation is subject to failure, as are markets" and commenting that "detailed regulation is not an option that economists have tended to view as a happy one").

82. See supra notes $16,17,22,81$ (considering administrability concerns with alternative approaches to antitrust intervention in this area).

83. See generally Glasner \& Sullivan, supra note 25 (discussing the fairly complicated and technical process of proper antitrust market definition); Jonathan Baker, Market Definition: An Analytical Overview 74 ANTITRUST L.J. 129, 129 (2007) (same); Gregory J. Werden, The 1982 Merger Guidelines and the Ascent of the Hypothetical Monopolist Paradigm, 71 ANTITRUST L.J. 253, 253-54 (2003) (same); Steven C. Salop, The First Principles Approach to Antitrust, Kodak, and Antitrust at the Millennium, 68 ANTITRUST L.J. 187, 189-90 (2000) (same).

84. See, e.g., Baker, supra note 6, at 129 ("Market definition is often the most critical step in 
these complicated fact questions surely would be at least as strenuously contested in any case brought on entrenchment grounds.

Second, the theory's focus on problems with existing competition necessitates an evaluation of current market power that is rarely needed in modern merger analysis. ${ }^{85}$ The proof problems inherent in measuring market power are not insuperable - in appropriate circumstances, market power may be indicated by price-cost margin data, patterns of behavior, or other reasonable evidence-but neither are they insignificant. ${ }^{86}$ Moreover, even with a proper measure of market power, there remains a question of the appropriate baseline. In short, how much market power is too much? Antitrust has largely avoided this question to date by focusing instead on opposing enhancements in market power, whatever the baseline might be. ${ }^{87}$ Here, antitrust would need to abandon this crutch, at least to the extent of identifying what types of market power would be appropriate targets for the remedial strategy of this approach. In other respects, however, reintegration of the entrenchment approach into merger enforcement would be fairly straightforward. Several seemingly serious hurdles turn out to be little challenge at all.

First, while it might seem like this approach could fail to satisfy the substantial lessening of competition standard of the Clayton Act, ${ }^{88}$ there is case law and commentary to the contrary. It must be recalled that the

evaluating market power and determining whether business conduct has or likely will have anticompetitive effects.").

85. See Massey, supra note 55, at 323 (expressing the now prevailing view that merger enforcement is primarily concerned with enhancements of market power); Werden, supra note 55, at 525-26 (similar); 2010 HORIZONTAL MERGER GUIDELINES, supra note 23, §§ 6-7 (similar); see also Carstensen, supra note 56, at 238 (describing, without adopting, this view).

86. See generally Lawrence J. White, Market Power and Market Definition in Monopolization Cases: A Paradigm Is Missing, in 2 ABA SECTION OF ANTITRUST LAW: ISSUES IN COMPETITION LAW AND POLICY 913 (Wayne D. Collins ed., 2008) (discussing closely related challenges in the context of establishing monopoly power under Section 2 of the Sherman Act); 2B PHILIP E. AREEDA, HERBERT HOVENKAMP \& JOHN L. SOlOW, ANTITRUST LAW ch. 5B, at 135-234 (4th ed. 2014) (considering various bases, other than market definition and market structure analysis, on which market power might be inferred).

87. See Kirkwood, supra note 57, at 1194 (noting that the common focus on the ability to increase price above the prevailing price "does not ask whether the prevailing level is 'competitive;' it [only] asks whether the defendant could increase price above that level"). The inquiry is different in some conduct cases under Section 2, which may provide some guidance for market power analysis under an entrenchment theory of merger enforcement. See, e.g., id. at 1197-1206 (discussing price increases relative to a "but for" price); White, supra note 86, at 914 (discussing the need for what is essentially a market power paradigm in monopolization analysis). But see Consolidated Version of the Treaty on the Functioning of the European Union art. 102, 2012 O.J. (C 326) 47 (making it a competition law violation for a firm in a "dominant position" to abuse its position by setting "unfair purchase or selling prices or other unfair trading conditions").

88. See AREEDA \& HOVENKAMP, supra note 21 , 1124 , at 62 (suggesting that a merger may not be said to reduce competition if "it only eliminates a future opportunity to increase it"); James A. Rahl, Applicability of the Clayton Act to Potential Competition, 12 SeC. ANTITRUST L. 128, 143 (1958) (asserting that the Clayton Act "does not prescribe a program for increasing competition. Its prohibition runs to conduct which actually or probably lessens competition."). 
Supreme Court itself suggested this approach, using it to enjoin mergers under the Clayton Act in cases that have never been overturned. ${ }^{89}$ And it is important to remember that - just like the entrenchment approach-all modern merger analysis is ultimately forward looking. ${ }^{90}$ The major difference is in the amount of specificity that each approach demands of predictions about future competition. Where competitive conditions are already poor, the entrenchment approach requires less specificity in the prediction of competitive gains than would be expected under the nowstandard preventative approach to merger enforcement.

Second, and on the topic of relaxed specificity requirements, another concern with the entrenchment approach might be that it could result in mergers being enjoined on the basis of "speculation" about future competition. $^{91}$ More precisely, the reduction in predictive specificity could result in more false-positive errors, where mergers are blocked without ultimately contributing to the improved competition for which they were enjoined. ${ }^{92}$ There is logic to this concern, but it must be placed in context. Because the entrenchment approach is only implicated in markets in which problematic market power is already being exercised, the relevant context will often be one with substantial costs for falsenegative errors. ${ }^{93}$ Failures to intervene in addressing the exercise of market power in this type of market are likely to result in the continued (and presumably durable) exercise of that power into the future. As a result, an optimal balance of errors - in this setting - may actually involve more false positives than one would expect of now typical merger enforcement. ${ }^{94}$ This is especially true where the remedy in question is

89. See supra notes 60-69 and accompanying text; Phillip Areeda, Market Definition and Horizontal Restraints, 52 ANTITRUST L.J. 553, 564 (1983) ("Merger precedents have been concerned not only with combinations creating new power but also with those reinforcing present power. One need not endorse all the cases making or misusing that point to accept the proposition that Clayton Act Section 7's prophylactic mandate is violated by a merger which reinforces pre-existing monopoly or oligopoly pricing.").

90. See Werden \& Limarzi, supra note 23, at 111.

91. Cf. United States v. Marine Bancorp., 418 U.S. 602, 622-23 (1974) (rejecting a proposed geographic market as "simply too speculative on this record" where there was "no persuasive showing that the effect of the merger [would be felt throughout this market]" and where the Court was asked to "assume, on the basis of essentially no evidence" that this effect would occur); Brown Shoe Co. v. United States, 370 U.S. 294, 323 (1962) (distinguishing mergers "with a probable anticompetitive effect" from those with only "ephemeral possibilities" of harm).

92. Cf. Louis Kaplow, Burden of Proof, 121 YALE L.J. 738, 756-62 (2012) (observing that less exacting burdens of persuasion will generally result in more false positives); Brooke Grp. Ltd. v. Brown \& Williamson Tobacco Corp., 509 U.S. 209, 223 (1993) (expressing concern that certain strict antitrust rules may create "intolerable risks of chilling legitimate [behavior]").

93. Cf. Lawrence M. Frankel, The Flawed Institutional Design of U.S. Merger Review: Stacking the Deck Against Enforcement, 2008 UTAH L. REV. 159, 192-99 (discussing the relative potential costs of false positives and false negatives in merger enforcement).

94. See generally Steven C. Salop, The Evolution and Vitality of Merger Presumptions: A 
merely injunction of a prospective merger, and not a more drastic intervention for which false-positive costs could be greater.

Third, and finally, while it might be objected that what I call the general entrenchment theory is a revisionist account of now dated cases, that objection falls flat in the antitrust context. ${ }^{95}$ From concerted action, to monopolization, to merger cases, nearly all of modern antitrust evolved from economic refinements and reinterpretations of earlier, less economically sophisticated ideas and opinions. ${ }^{96}$ In this light, the entrenchment theory is simply one component of old antitrust that was passed over in the broader update. The following parts of this article illustrate the gains that could await its revitalization today.

\section{APPLICATION: TACITLY COLLUDING OLIGOPOLY}

In markets with few sellers and unattractive opportunities for entry, it is well known that soft competition and conditions closer to cooperation than competition can take hold. ${ }^{97}$ These uncompetitive patterns of interaction can arise without any express agreements between competitors, ${ }^{98}$ though the results may be the same as explicit collusion, ${ }^{99}$ if not worse. ${ }^{100}$ As a prototypical example of the exercise of market power

Decision-Theoretic Approach, 80 ANTITRUST L.J. 269, 296-98 (2015) (recommending a decisiontheoretic approach to merger enforcement which considers the costs of decision errors in rule formulation); Frankel, supra note 93, at 159-60 (critiquing current U.S. merger review as tending to produce too many false negatives).

95. Cf. Hosp. Corp. of Am. v. FTC, 807 F.2d 1381, 1385 (7th Cir. 1986) (Posner, J.) (chiding the FTC for "studiously avoiding reliance on any of the Supreme Court's section 7 decisions from the 1960s except United States v. Philadelphia Nat'l Bank").

96. See generally William E. Kovacic \& Carl Shapiro, Antitrust Policy: A Century of Economic and Legal Thinking, 14 J. ECON. PERSP. 43 (2000) (chronicling the convergence of legal and economic thinking over the history of the antitrust statutes); see also Kimble v. Marvel Entm't, LLC, $135 \mathrm{~S}$. Ct. 2401, 2412-13 (2015) (noting the special plasticity of antitrust law with respect to changes in economic thinking).

97. BAKER, supra note 6, at 3 ("Even more troubling, cartel prosecutions by the Justice Department are probably only the tip of a large market-power iceberg arising from coordinated conduct among oligopolists .... That's why it is reasonable to infer from the cartel statistics that the exercise of market power arising from anticompetitive coordinated conduct is common in oligopoly markets.").

98. See Richard A. Posner, Antitrust Law 52 (2d. ed. 2001) ("[I]n some circumstances, competing sellers might be able to coordinate their pricing without conspiring in the usual sense of the term - that is, without any overt or detectable acts of communication."). But see Jonathan B. Baker, Two Sherman Act Section 1 Dilemmas: Parallel Pricing, the Oligopoly Problem, and Contemporary Economic Theory, 38 ANTITRUST BULL. 143, 145 (1993) (suggesting that agreement could be inferred from the deliberative process of tacit collusion).

99. MARTIN, supra note 81, at 697 ("[I]f the number of firms is small, independent action can lead to results that closely approximate those of collusion.").

100. As discussed in Section IV.A, modern antitrust offers few impediments to the exercise of market power in this arrangement. This is problematic, given the apparent durability of market power when patterns of coordination take hold. See, e.g., Margaret C. Levenstein \& Valerie Y. Suslow, 
in highly concentrated markets, tacit collusion among oligopolists is a prime target for an entrenchment theory of merger control.

\section{A. Insufficiency of Existing Antitrust Concepts}

The value of the entrenchment approach is greatest where other elements of the antitrust framework are unable to address an existing market power and market concentration problem. In this respect, one of the most frustrating blind spots of modern antitrust is its inability to address tacit collusion among oligopolists. ${ }^{101}$ While things like express price fixing are clearly illegal under Section 1 of the Sherman Act, ${ }^{102}$ equivalent conduct reached by experience and inference, but without express agreement, appears all but untouchable today.

The difficulty of reaching the conduct of tacit collusion under Section 1 is well known. Ever since the Supreme Court decided Theater Enterprises, Inc. v. Paramount Film Distributing Corp. in 1954, ${ }^{103}$ there has been no serious argument that merely parallel conduct could constitute an antitrust violation. ${ }^{104}$ Liability under Section 1 requires an agreement. ${ }^{105}$ There are quite sensible reasons for this rule, but it means that if competitors can manage to coordinate their conduct without forming any actual "agreement" to do so, they can achieve all the benefits of collusion without any risk of liability for doing so. ${ }^{106}$ This is not a theoretical or academic point. Recent cases offer stark illustrations of both

Breaking Up Is Hard to Do: Determinants of Cartel Duration, 54 J.L. \& ECON. 455, 463 (2011) (discussing the determinants of cartel stability in relation to data in which the average duration of cartels was roughly eight years, with a median duration of seven years); see generally Barbara Alexander, The Impact of the National Industrial Recovery Act on Cartel Formation and Maintenance Costs, 76 REV. ECON. STAT. 245 (1994) (describing evidence that, once cartels are formed, they may remain durable and functional for an extended period, even if subsequent conditions are hostile to coordination).

101. MARTIN, supra note 81, at 697 ("In both the U.S. and the EU, genuinely independent business decisions are not condemned by laws that ban collusion, even if the independent decisions lead to market outcomes that are indistinguishable from those of collusion. This is the heart of the problem that oligopoly presents for the enforcement of competition law ....").

102. United States v. Socony-Vacuum Oil Co., 310 U.S. 150, 223 (1940) ("Under the Sherman Act a combination formed for the purpose and with the effect of raising, depressing, fixing, pegging, or stabilizing the price of a commodity in interstate or foreign commerce is illegal per se.").

103. 346 U.S. 537 (1954).

104. MARTIN, supra note 81, at 692, 695-96 (noting the demise of the doctrine of conscious parallelism with Theater Enterprises); Kovacic \& Shapiro, supra note 96, at 50 ("After toying with the possibility of treating oligopolistic interdependence as a form of agreement, the Supreme Court [ruled in Theatre Enterprises] that proof of 'conscious parallelism,' without more, could not... establish an antitrust violation.").

105. Hovenkamp, supra note 24 , at 52 ("[C]ollusion-like behavior can be condemned only if the conduct satisfies the 'agreement' requirement of section 1 of the Sherman Act. Many instances of acknowledged conscious parallelism do not.").

106. Baker, supra note 6, at 5 ("[B] usinesses are taught to exploit gaps in antitrust rules to engage in coordinated conduct without running afoul of those rules."). 
the existence of tacit collusion, and the inability of antitrust to do anything about it. ${ }^{107}$

Even attempts to reach tacit collusion on Section 1 grounds by inferring an implied agreement to collude have proven largely unsuccessful at addressing this anticompetitive conduct. Perversely, though with some logic, courts tend to view the tightness of an oligopoly as a factor that actually militates against the inference of an agreement. ${ }^{108}$ In a concentrated market in which all firms predict an unwinding of super competitive profits if they were to engage in aggressive competition, why would any agreement be needed for each firm individually to conclude that soft competition is the best strategy?

Although merger enforcement has long been thought especially important as a way of preventing this type of market structure from taking hold, ${ }^{109}$ there seems to be less recognition that modern merger enforcement policy is actually poorly equipped to deal with situations in which tight oligopolistic coordination is already underway. A detailed defense of this claim requires more space than I can devote here, but two brief observations will illustrate the point.

First, the focus of modern merger enforcement on enhancements of market power typically leads market definition to use the current price as the baseline against which price increases are compared when defining

107. E.g., Valspar Corp. v. E.I. Du Pont De Nemours \& Co., 873 F.3d 185, 191-96 (3d Cir. 2017) (stating the rule that conscious parallelism is "beyond the reach of antitrust laws" and concluding that evidence of "31 parallel price increase announcements" failed to prove more than the "mere interdependence" of competitors); In re Text Messaging Antitrust Litig., 782 F.3d 867, 871-77 (7th Cir. 2015) (Posner, J.) (affirming summary judgment for defendants on a record "consistent with tacit as well as express collusion," in part because "the fewer the firms, the easier it is for them to engage in 'follow the leader' pricing ... which means coordinating their pricing without an actual agreement to do so."); Williamson Oil Co. v. Philip Morris USA, 346 F.3d 1287, 1291 (11th Cir. 2003) (affirming a district court holding that "[cigarette] manufacturers' pricing behavior evidenced nothing more than 'conscious parallelism,' a perfectly legal phenomenon commonly associated with oligopolistic industries" when appellants could not produce sufficient evidence tending to exclude the possibility of independent action).

108. Hovenkamp, supra note 24, at 53 ("Numerous Sherman Act section 1 decisions involving tight oligopoly industries have rejected price fixing allegations by concluding that conspiracies are more difficult to prove in such markets than in those that are more competitively structured."). But see Christopher R. Leslie, The Probative Synergy of Plus Factors in Price-Fixing Litigation, 115 NW. U. L. REV. (forthcoming 2020) (sharply criticizing the reasoning of opinions that have failed to infer agreements to collude among the members of tight oligopolies).

109. See Shapiro, supra note 11, at 738 ("Merger enforcement is especially important since a wide range of interdependent conduct by oligopolists, i.e., conduct whereby the oligopolists refrain from vigorous competition, is not considered to be illegal if it does not involve an agreement among those oligopolists."); MARTIN, supra note 81, at 697 ("A clear implication of the oligopoly problem is that if there are practical difficulties in influencing business conduct in oligopoly markets, competition authorities should take great care in administering policy toward market structure. A proposed merger that would lead to market structures conducive to tacit collusion should be vetted, keeping in mind the oligopoly problem that might arise in the post-merger market."). 
relevant markets in merger cases. ${ }^{110}$ Where the concern is that a merger will create new market power, this approach makes perfect sense. But where an oligopoly is already tacitly colluding, defining markets relative to the collusive prevailing price tends to produce broad relevant markets in which competition looks stronger and less conducive to the exercise of market power than it actually is. ${ }^{111}$

Second, the now standard approach to proving coordinated effects in merger cases asks how a merger will make a market more vulnerable to coordination than it would be without the merger, ${ }^{112}$ expressly seeking evidence other than the structural effect of the merger itself. ${ }^{113}$ The strongest argument contemplated by the current Merger Guidelines is a merger involving the acquisition of a maverick firm that has previously rebuffed the efforts of other competitors to collude. ${ }^{114}$ But where tight oligopolists are already tacitly colluding, evidence that a merger would lead to any specific enhancement in collusion may be weak to nonexistent. The only remarkable thing about this statement is that it might be interpreted as an argument against antitrust intervention. The intuitive problem with such a merger is not that it will enhance market power. The problem is that it will entrench market power.

110. See supra note 87 and accompanying text (noting this regularity). While the Merger Guidelines accept the use of different baseline prices in certain circumstances, the conditions needed to justify deviation from the prevailing price norm are restrictive. See Glasner \& Sullivan, supra note $25, \S$ II.B.2.

111. In the context of monopolization cases, this problematic approach to market definition is commonly called the Cellophane fallacy. See POSNER, supra note 98, at 150-51 (providing a textbook summary of the Cellophane fallacy).

112. 2010 Horizontal Merger Guidelines, supra note 23, § 7.1 (focusing on "whether a merger is likely to change the manner in which market participants interact, inducing substantially more coordinated interaction"); $i d$. (seeking "a credible basis on which to conclude that the merger may enhance that vulnerability"); see also Herbert Hovenkamp, Harm to Competition Under the 2010 Horizontal Merger Guidelines, 39 REV. INDUS. ORGAN. 3, 13 (2011) ("[W]hat happened during the 1990 s and a little after is that the 'other factors' portions of the Guidelines ended up doing much more of the work, and Guidelines' structural presumptions became much less important."); Carstensen, supra note 56, at 242 ("Such merger-specific prediction discourages challenge to even significant structural change because of the difficulty in 'proving' that some specific effect is likely to happen within some relatively short period of time.").

113. Jonathan B. Baker, Mavericks, Mergers, and Exclusion: Proving Coordinated Competitive Effects Under the Antitrust Laws, 77 N.Y.U. L. REV. 135, 139 (2002) (referring to structural determinants of coordination as the "dinner party story" and critiquing this evidence of coordination on the basis that "the dinner party story does not answer the question of why the particular merger under review is likely to help the industry solve its coordination problems").

114. See 2010 HorizOnTAL MERGER GuIDELINES, supra note 23, §§ 2.1.5, 7.1; see also Baker, supra note 6, at 177-79 (using the concept of the maverick to distinguish anticompetitive and procompetitive mergers). 


\section{B. Promise of an Entrenchment Theory}

It is straightforward to apply the entrenchment theory of merger enforcement to the fact pattern of a tacitly colluding oligopoly. Almost by definition, such an oligopoly is going to satisfy the first requirement of the entrenchment approach: an already concentrated relevant market. In fact, as I have argued elsewhere, proper market definition - when conducted in relation to entrenchment theories-should take some version of the competitive price as its baseline. ${ }^{115}$ This suggests that relevant markets in entrenchment cases may often be narrower than they would be under the now typical preventative approach to merger enforcement. That is, the previously noted and perverse expansion of relevant markets when firms are already tacitly colluding should not arise when a merger is being challenged on entrenchment grounds.

Proof of the ongoing exercise of market power also appears straightforward in the context of ongoing tacit collusion. The crux of recent cases on the topic has not been doubt about the exercise of market power-which is evinced by rising profits, multiple price increases, pricing announcements, and the like - but doubt about the existence of an "agreement" to do so. ${ }^{116}$ This is no obstacle for the entrenchment approach to merger enforcement, as the Clayton Act does not require any agreement to intervene. ${ }^{117}$ The entrenchment approach is satisfied by the ability to exercise market power in such a market structure.

Finally, absent special circumstances, concentration of the relevant market will typically be a contributor to the exercise of market power via tacit collusion. The more tightly concentrated the market is, the more likely a court is to infer that parallel conduct is being fostered by interdependence and not agreement. Indeed, it is this very logic upon which tacitly colluding oligopolists escape Section 1 liability. ${ }^{118}$ Having the benefit of that structural inference in one respect, the members of a tight oligopoly cannot credibly deny it in another respect.

This not only completes the requirements of the entrenchment theory of harm, but also justifies an injunctive remedy. The entrenchment approach to merger enforcement prescribes aggressive injunction of mergers in relevant markets in which tacit collusion already appears to be

115. See Glasner \& Sullivan, supra note 25, § II.B.1 (discussing the need to calibrate the baseline price in the hypothetical monopolist test in relation to different theories of harm).

116. See Valspar Corp. v. E.I. Du Pont De Nemours \& Co., 873 F.3d 185, 191-96 (3d Cir. 2017); In re Text Messaging Antitrust Litig., 782 F.3d 867, 871-77 (7th Cir. 2015); Williamson Oil Co. v. Philip Morris USA, 346 F.3d 1287, 1291 (11th Cir. 2003).

117. See, e.g., Hovenkamp, supra note 24, at 47 ("Section 7 has no agreement requirement, such as that which limits enforcement of section 1 of the Sherman Act.").

118. Valspar Corp., 873 F.3d at 191-96; In re Text Messaging Antitrust Litig., 782 F.3d at 87177; Williamson Oil Co., 346 F.3d at 1291; Hovenkamp, supra note 24, at 53. 
ongoing. The point of injunction is not, to repeat, the now-standard objective of trying to prevent an incremental price increase as a result of the merger. The point is to preserve all opportunities for competitive frictions eventually to cause breakdowns in coordination, ${ }^{119}$ hopefully securing more competitive future outcomes than consumers enjoy today.

Of course, even if the entrenchment theory is justified in the extreme case of clear and ongoing tacit collusion, the approach could still be objected to as a potentially very difficult inquiry in borderline cases where market structure and market power are both seriously in dispute. The only defense to this critique is that the alternative-in which tacit collusion is entirely beyond the reach of antitrust - is costly as well. The same critique, admission, and response applies to the equally valid observation that this approach to merger enforcement would require an assessment of how much of an exercise of market power is enough to justify intervention - a point discussed earlier in this article. ${ }^{120}$

Other critiques are less persuasive.

It might be objected, for example, that the obstruction of a merger on entrenchment grounds could result in firms failing to achieve scale or other productive efficiencies. The scale argument starts from an unsure footing, since the entrenchment theory only applies to already concentrated markets. But giving it the benefit of the doubt for sake of argument, this and other efficiencies can be raised as part of an efficiencies defense in the entrenchment context. ${ }^{121}$ True, the comparison of short-term efficiencies to long-term potential benefits of incremental competitive friction could be a challenging exercise, but the assessment of merger efficiencies is hardly much cleaner today. ${ }^{122}$

A similar objection could be raised that a heavy-handed application of the entrenchment approach could prevent a firm from efficiently exiting from a concentrated but actually oversaturated market, essentially requiring the firm to exit through liquidation instead of acquisition. ${ }^{123}$

119. Cf. Christopher R. Leslie, Trust, Distrust, and Antitrust, 82 TeX. L. REv. 515, 564-95 (2004) (discussing competitive tensions and the modulation of trust among cartel participants); ALFRED D. Chandler, JR., The Visible Hand: The MANagerial Revolution in AMERICAN Business 31620 (1977) (detailing the early formation of trade associations to manage collusion among member firms, and the tendency of these cartels to adopt the forms of trust or merger as a way of mitigating otherwise frequent problems of destabilizing cheating and secret defection).

120. See supra notes $85-87$ and accompanying text (discussing this complication and positioning it in the context of other antitrust actions).

121. See 2010 Horizontal Merger Guidelines, supra note $23, \S 10$.

122. See Sean P. Sullivan, Lumps in Antitrust Law, U. CHI. L. REV. OnLINE (Mar. 30, 2020), https://lawreviewblog.uchicago.edu/2020/03/30/lumps-in-antitrust-law-by-sean-p-sullivan/ [https:// perma.cc/3VZ4-3PY4] (discussing the difficulty of assessing merger efficiencies under current antitrust norms).

123. Models of oligopolistic competition rarely allow for an infinite number of firms to participate 
This, too, could be raised and considered as a straightforward application of the failing firm defense. ${ }^{124}$

Finally, it might be objected that this entrenchment approach requires the government to reach into the business conduct of oligopolists, coming close to the bureaucratic regulation of businesses that antitrust policy has historically eschewed. There is some truth to this, but it must be placed in context. As already discussed, the typical preventative approach to coordination cases faces substantial hurdles where tacit collusion has already taken hold. ${ }^{125}$ And in terms of conduct challenges, the chief argument raised in response to suggestions that tacit collusion should be reached by Section 1 is that courts cannot practically regulate business conduct or force a business to compete. ${ }^{126}$ This being the case, the preservation of existing competition, however imperfect, may be the only plausible remedy for the problem of tacit collusion where it occurs. ${ }^{127}$ To retreat from the entrenchment theory as too interventionist is essentially to concede the field. ${ }^{128}$

\section{APPLICATION: DOMINANT FIRM IN A PROTECTED POSITION}

Another example of the potentially durable exercise of market power in a concentrated market involves a dominant firm protected by scale effects, network effects, or similar barriers to entry. The emergence of such a firm need not result from any exercise of exclusionary or anticompetitive conduct. Market concentration and the rise of dominant firms may, for example, be all but inevitable in the case of natural

\footnotetext{
in the market and still earn non-negative profits. See, e.g., Carl Shapiro, Theories of Oligopoly Behavior, in 1 HANDBOOK OF INDUSTRIAL ORGANIZATION 239, 336 (R. Schmalensee \& R.D. Willig eds., 1989) (noting that firms in Cournot equilibrium are not generally guaranteed non-negative profits if the number of market participants is sufficiently large); Avner Shaked \& John Sutton, Natural Oligopolies, 51 ECONOMETRICA 1469, 1469-70 (1983) (describing a related property in qualitydifferentiated competition).

124. See 2010 Horizontal Merger Guidelines, supra note 23, § 11.

125. See supra notes $110-114$ and accompanying text.

126. E.g., Clamp-All Corp. v. Cast Iron Soil Pipe Inst., 851 F.2d 478, 484 (1st Cir. 1988) (Breyer, J.) ("[I]t is close to impossible to devise a judicially enforceable remedy for 'interdependent' pricing. How does one order a firm to set its prices without regard to the likely reactions of its competitors?"); In re Text Messaging Antitrust Litig., 782 F.3d 867, 874 (7th Cir. 2015) (Posner, J.) (“A seller must decide on a price; and if tacit collusion is forbidden, how does a seller in [a tight, oligopolistic market] decide what price to charge? If the seller charges the profit-maximizing price (and its 'competitors' do so as well), and tacit collusion is illegal, it is in trouble. But how is it to avoid getting into trouble?").

127. See Hovenkamp, supra note 24 , at 47 ("The appropriate use of incipiency tests is to prevent certain bad outcomes early when antitrust rules make it difficult or impossible to prevent them later.").

128. Cf. Howard Shelanski, Antitrust and Deregulation, 127 YALE L.J. 1922 (2018) (discussing the special role of antitrust in areas where other forms of regulation are weak or absent).
} 
monopolies, ${ }^{129}$ or the production of goods and services subject to winnertake-most properties. ${ }^{130}$ But this does not mean that the exercise of market power by a dominant firm in such a position is not still problematic, ${ }^{131}$ nor that consumers could not benefit from a greater number of independent competitors. $^{132}$ Here, again, an entrenchment approach to merger enforcement may offer solutions that elude contemporary antitrust policy.

\section{A. Ineffectiveness of Common Theories}

The exercise of monopoly power by a durable monopolist is similar to tacit collusion in the sense that it, too, is insulated from disturbance by modern antitrust policy. The evolution of monopolization analysis under Section 2 of the Sherman Act has placed beyond dispute the proposition that a dominant firm can legally exercise market power, ${ }^{133}$ and also that it can legally seek to obtain market power in all but a narrow variety of exclusionary ways. ${ }^{134}$ This permissive approach to the exercise of market power is defensible on many grounds, ${ }^{135}$ and may be the wisest course of action in situations where monopoly is contested or the exercise of market power is transient.

But it leaves a gap in antitrust's protection of consumers. If a firm acquires a dominant position with the protection of barriers to entry, substantial scale or network effect advantages, or similar impediments to contestability, then it may unleash all the evils of monopoly with little fear

129. See generally, John E. Kwoka, The Role of Competition in Natural Monopoly: Costs, Public Ownership, and Regulation, 29 REV. INDUS. ORG. 127 (2006) (discussing the formation and consequences of natural monopoly and potential gains from competition within this type of market).

130. Cf. Richard Schmalensee, Antitrust Issues in Schumpeterian Industries, 90 AM. ECON. REV. 192 (2000) (noting differences in the interpretation of competitive motive in winner-take-all markets); A. Douglas Melamed, Network Industries and Antitrust, 23 HARV. J.L. \& PUB. POL'Y 147 (1999) (discussing how competition subject to large network effects relates to traditional antitrust analysis).

131. Even "natural monopoly" exhibits the properties of monopoly. In the single-price context, for example, it entails pricing above the socially efficient level and deadweight loss. Depending on the circumstances, natural monopoly may or may not exhibit rent seeking inefficiencies as well. $C f$. POSNER, supra note 98, at 13-15 (discussing rent seeking inefficiencies when firms use certain activities to gain market power).

132. See Baker, supra note 6, at 5 ("[Large tech platforms] have delivered substantial consumer benefits, and their conduct does not necessarily violate antitrust laws. Yet consumers and the U.S. economy as a whole would likely benefit even more if they faced greater competition."); Kwoka, supra note 129 (observing potential social gains from competition, even within markets tending toward natural monopoly).

133. Verizon Commc'ns Inc. v. Law Offices of Curtis V. Trinko, LLP, 540 U.S. 398, 407 (2004) ("The mere possession of monopoly power, and the concomitant charging of monopoly prices, is not only not unlawful; it is an important element of the free-market system.").

134. See 3 Philip E. AREeda \& Herbert HovenKamp, ANTitrust LaW ch. 7, at 199-221 (4th ed. 2015) (discussing historically important patterns of anticompetitive monopolization conduct).

135. E.g., Brooke Grp. v. Brown \& Williamson Tobacco Corp., 509 U.S. 209, 223 (1993) (propounding a permissive rule on preparatory price, partly in recognition that low prices generally benefit consumers). 
of repercussion from either market forces or antitrust. ${ }^{136}$ To some observers, the rise of large and ostensibly uncontested technology companies exemplifies this problem today. ${ }^{137}$

Especially concerning, given this hands-off treatment, is the acquisition of nascent rivals by dominant firms. These acquisitions are within the reach of antitrust law: they could, for example, be attacked as the maintenance of monopoly under Section 2, or as acquisitions tending substantially to lessen competition under Section 7. ${ }^{138}$ In a few extreme cases, like a monopolist buying its only rival, these laws provide a straightforward path to intervention. ${ }^{139}$ But in most cases, the acquisition of a small or nascent rival enjoys powerful insulation against antitrust interference.

The challenges for enforcement are similar to those facing opposition to mergers of firms that are already tacitly colluding, discussed above in Section IV.A. One is the possible expansion of relevant markets where the dominant firm is already exercising its market power at the time it acquires a still nascent rival. ${ }^{140}$ This problem is similar enough to that discussed in the tacit collusion context that it does not require repetition here. The other and more serious problem is the difficulty of predicting specific competitive injuries in this situation.

As before, the need for specific prediction arises from the preventative focus of modern antitrust analysis. Intervention is usually premised on the articulation of a fact-based "reasonable probability" that the acquisition will substantially lessen future competition. ${ }^{141}$ Arguably, the required

136. See AREEDA \& HovenKAMP, supra note 134, $934 \mathrm{~b}$, at $77-78$ (making a similar point).

137. Cf. Jack Nicas, Karen Weise \& Mike Isaac, How Each Big Tech Company May Be Targeted by Regulators, N.Y. TIMES (Sept. 8, 2019), https://www.nytimes.com/2019/09/08/technology/antitrust -amazon-apple-facebook-google.html [https://perma.cc/Y4FX-B7Y9].

138. See United States v. Grinnell Corp., 384 U.S. 563, 570-71 (1966) (identifying the "maintenance of [monopoly] power" as conduct falling within the offense of monopoly); Clayton Act, ch. 323, § 7, 38 Stat. 730, 731-32 (1914) (current version at 15 U.S.C. § 18 (2012)) (prohibiting mergers, the effects of which "may be to substantially lessen competition ..., or tend to create a monopoly").

139. See AREEDA \& HovenKAMP, supra note 134, ๆ 701c, at 202-03 ("Suppose that a monopolist who has long supplied 99 percent of its market acquired the one firm supplying the remainder of that market. The acquisition should be prevented even if we assume that the small firm would probably continue to play only a very minor role."); $i d$. $9701 \mathrm{~d}$, at 203-05 (applying similar reasoning to a monopolist's acquisition of a "unique" potential competitor).

140. See supra notes 110-11 and accompanying text (explaining how the ongoing exercise of market power may result in a broad relevant market under the now-standard approach to market definition in merger analysis). It is less clear that this artificial expansion of the relevant market would apply under maintenance of monopoly analysis. See generally White, supra note 86 (discussing market definition in monopolization analysis).

141. See United States v. Siemens Corp., 621 F.2d 499, 506-07 (2d Cir. 1980) (requiring "for purposes of determining whether such relief is appropriate ... at least a 'reasonable probability' that the acquiring firm would enter the market... and preferably clear proof that entry would occur" 
showing is lower where the acquisition is by a monopolist and involves a rival that is competitively superior to other nascent rivals. ${ }^{142}$ But the distinction seems modest, since demonstration of competitive distinctiveness presents many of the same proof problems as the "reasonable probability" standard itself.

Those proof problems can be severe. Since the nascent rival isalmost by definition - not yet competing at the level it might in the future, intervention rests on a credible prediction of future competitive success that may be difficult or impossible to build upon the limited record of its behavior to date. In special cases, like the acquisition of a rival with an important patent right, this showing may be possible. ${ }^{143}$ But in other cases, demonstration of a nascent firm's specific importance to future competition can be difficult indeed.

It is especially troubling to note that this state of enforcement policy actually creates perverse incentives for nascent firms to avoid competing too aggressively with dominant rivals. Acquisition by a dominant firm may be a lucrative proposition for the small firm's stakeholders. And since the prospects of easy acquisition decrease as a nascent firm builds a record of successful competition, new and potentially disruptive firms actually have a good reason to think twice before they begin to engage in serious competition with a larger rival under the current framework.

\section{B. Promise of an Entrenchment Theory}

Here, too, it is straightforward to apply the entrenchment theory of merger enforcement to this otherwise problematic fact pattern. The focus on acquisitions by a dominant firm means that the requirement of an already concentrated market is satisfied by construction. Though it remains a matter to be proven, evidence of current market power is likely to exist as well. Whether on structural or behavioral grounds, the possession of "monopoly power" already contemplates something like

(citations omitted)); Mercantile Tex. Corp. v. Bd. of Governors Fed. Reserve Sys., 638 F.2d 1255, 1268-69 (5th Cir. 1981) (adopting this "reasonable probability" requirement and explaining that it encompasses a "persuasive rationale demonstrating [why future competition would unfold as predicted]"); see also Werden \& Limarzi, supra note 23, at 122 ("[T] he rationale usually is that the acquisition would eliminate the 'reasonable probability' that the nascent rival would have a substantial impact on future competition.").

142. See AREEDA \& HovenKAMP, supra note 134, 9ף 701c-701e, at 202-06 (contemplating less exacting proof requirements where a monopolist acquires a unique rival, but returning to concerns about speculation and the need for more specific proof where the acquired firm is not different from other small and nascent rivals).

143. See, e.g., Hovenkamp, supra note 112, at 9 (discussing the serious threat to competition posed by the acquisition and nonuse of an important patent). 
substantial market power today. ${ }^{144}$

The final requirement, that current market concentration is facilitating the exercise of market power, also seems unlikely to present a serious challenge. To the extent that things like unique scale or currently advantageous network effects are the drivers of dominance and market power, the presence of rivals with the capacity to contest these advantages would presumably limit and possibly reverse the exercise of market power. ${ }^{145}$ There is again a parallel between this inference and the permissive treatment of dominant firms today. One cannot simultaneously believe that competition and contestability will often constrain dominant firms while doubting that concentration and an absence of serious competitors will facilitate the exercise of market power. ${ }^{146}$

The entrenchment approach to merger enforcement prescribes the aggressive injunction of mergers in situations in which a dominant firm seeks to acquire even a nascent and uncertainly competitive rival. This satisfies calls in the antitrust literature for enhanced enforcement against acquisitions of nascent and potential rivals. ${ }^{147}$ That result is important, but the path to the result matters more. The entrenchment approach sidesteps the current enforcement roadblock of needing to prove uncertain future competitive effects by instead focusing attention on the anticompetitive status of the market today. The point of enjoining the acquisition of small and nascent firms in this approach is not to prevent any specific lessening of future competition (the preventative objective). Rather, the point is to preserve existing opportunities for future competition where conditions are already quite bad, even when specific predictions of competitive effects are not yet possible on the available evidence (the entrenchment objective).

As before, this approach has the attractive property that it addresses a gap in the modern antitrust framework without requiring drastic policy changes that would be involved, for example, in a strategy of breaking up

144. See, e.g., United States v. E.I. Du Pont de Nemours \& Co., 351 U.S. 377, 391 (1956) ("Monopoly power is the power to control prices or exclude competition.").

145. This argument seems especially strong in the tech context. See, e.g., Wessel, supra note 3, at 113 ("Acquisitions that in the past were too small to attract the usual antitrust scrutiny can eliminate potential competition, especially in a world where a company like WhatsApp can grow in just a few years to reach a billion users a day.").

146. Cf. Carstensen, supra note 56, at 220-21 ("Markets are dynamic and the future is notoriously unpredictable .... What is essential from the perspective of competition policy is to have a significant number of firms competing in price, quality, and innovation.").

147. E.g., Shapiro, supra note 11, at 739-40 ("One promising way to tighten up on merger enforcement would be to apply tougher standards to mergers that may lessen competition in the future, even if they do not lessen competition right away. In the language of antitrust, these cases involve a loss of potential competition."); Hovenkamp, supra note 24, at 70 ("A large firm's acquisition of a small, highly innovative firm can raise serious long run competition issues, even if the two firms are not competitors at the time of the acquisition. Such an acquisition may not have an immediate impact on price."). 
dominant firms or subjecting their business decisions to governmental regulation. One might object that the entrenchment approach "punishes" large firms for obtaining dominance, ${ }^{148}$ but relative to other possible interventions, the prohibition on acquiring nascent rivals seems a modest burden. ${ }^{149}$ This is especially true in light of the previously noted availability of an efficiencies defense, in which the dominant firm would be free to prove how acquiring a rival would enable it to achieve special and socially productive capabilities that its scale and resources do not already allow. ${ }^{150}$

Concerns that this entrenchment approach to dominant firms could lead to excessive interference and injunction of benign acquisitions are reasonable, but ultimately unpersuasive. As noted previously, ${ }^{151}$ the optimal balance of false-positive and false-negative errors actually leans in favor of relatively more false positives (more aggressive enforcement) when the market power implications of a false negative are otherwise largely outside the reach of antitrust intervention. ${ }^{152}$

A more circumspect answer must be given to the concern that small firms, relying on acquisition as a form of compensation, may have less incentive to enter and innovate under the strictures of the entrenchment approach. ${ }^{153}$ This concern relies on two implicit assumptions: (1) that incentives for innovation and entry are not currently super optimal and (2) that alternative buyers would not exist to take the place of a dominant firm. But subject to these qualifiers, it is a fair critique of the entrenchment approach. The cost may be justified by benefits of greater future competition under this approach, but it should not be ignored. ${ }^{154}$

148. United States v. Aluminum Co. of Am., 148 F.2d 416, 430 (2d Cir. 1945) ("The successful competitor, having been urged to compete, must not be turned upon when he wins.").

149. See Hovenkamp, supra note 24, at 73-74 (making a similar point about the low cost of preventing a prospective merger, relative to other antitrust remedies).

150. See Shapiro, supra note 11, at 740 (noting the problem of distinguishing typical acquisitions of nascent rivals from situations "in which the dominant incumbent can and will greatly expand the reach and usage of the target firm's products"); supra note 121 and accompanying text (discussing the availability of an efficiencies defense in modern merger analysis).

151. See supra note 94 and accompanying text (discussing error cost balancing).

152. Cf. Shapiro, supra note 11, at 741 ("[T] and innovation if the DOJ and FTC could selectively prevent mergers that serve to solidify the positions of leading incumbent firms, including dominant technology firms, by eliminating future challengers .... Sound competition policy would tolerate some false positives ... in order to avoid some false negatives ....").

153. Cf. United States v. Von's Grocery Co., 384 U.S. 270, 301 (1966) (Stewart, J., dissenting) ("[B]y foreclosing future sale as one attractive avenue of eventual market exit, the Court's decision may over the long run deter new market entry and tend to stifle the very competition it seeks to foster.").

154. See generally Kevin A. Bryan \& Erik Hovenkamp, Startup Acquisitions, Error Costs, and Antitrust Policy, 87 U. CHI. L. REV. 331 (2020) (arguing for greater antitrust enforcement against the acquisition of startup firms by dominant incumbents); Mark A. Lemley \& Andrew McCreary, Exit 
Finally, one might question whether the entrenchment approach can be contained once it is unleashed. The discussion of this paper has been limited to nascent competitors (i.e., current but small rivals), but the approach could be extended to potential competitors and firms in adjacent markets. ${ }^{155}$ This may, in fact, be necessary to address concerns about technology competition, ${ }^{156}$ as well as some concerns about mergers of healthcare providers. ${ }^{157}$ The difficulty of identifying clear limiting principles is a valid and important concern, but not necessarily a fair critique of the entrenchment approach in comparison to other strategies for addressing current concentration and market power concerns. Any effort to address problems in areas as complicated as innovation and technology competition is going to face challenges in defining the appropriate scope of competitors. Relative to some of the more novel and sweeping reform proposals, situation of the entrenchment approach within the modern antitrust framework gives it at least a fighting chance of getting these difficult scope questions close to right. ${ }^{158}$

Strategy (Stan. Law \& Econ. Olin Working Paper Series, Paper No. 542, 2019), https://ssrn.com/abstract=3506919 [https://perma.cc/KKM8-W2NP] (documenting the negative consequences of consistent start-up acquisition and considering alternative ways to fund innovation); D. Daniel Sokol, Vertical Mergers and Entrepreneurial Exit, 70 FLA. L. REV. 1357 (2018) (discussing the need to balance competitive concerns against the efficiency of entrepreneurial exit when nascent rivals are acquired by tech companies).

155. See Werden \& Limarzi, supra note 23, at 123 ("In the same sense that nascent competition has just recently crossed the line separating 'potential' from 'actual' competition, imminent competition will soon cross the line."); AREEDA \& HOVENKAMP, supra note 134, q9 701c-701e, at 202-06 (discussing similarities in the acquisitions of "small," "potential," and "related" competitors). Indeed, the Supreme Court's analysis of potential competition in FTC v. Proctor \& Gamble Co. aligns with the entrenchment approach in important respects. E.g., 386 U.S. 568, 578 (1967) (observing, in the process of upholding injunction of a conglomerate merger, that the acquired company's "industry was already oligopolistic before the acquisition, and price competition was certainly not as vigorous as it would have been if the industry were competitive").

156. See, e.g., Shapiro, supra note 11, at 740 ("One common fact pattern that can involve a loss of future competition occurs when a large incumbent firm acquires a highly capable firm operating in an adjacent space.... Acquisitions like these can lessen future competition, even if they have no such immediate impact.").

157. See, e.g., Leemore Dafny, Kate Ho \& Robin S. Lee, The Price Effects of Cross-Market Mergers: Theory and Evidence from the Hospital Industry, 50 RAND J. ECON. 286 (2019); Matthew S. Lewis \& Kevin E. Pflum, Hospital Systems and Bargaining Power: Evidence from Out-of-Market Acquisitions, 48 RAND J. ECON. 579 (2017); Gregory S. Vistnes \& Yianis Sarafidis, Cross-Market Hospital Mergers: A Holistic Approach, 79 ANTITRUST L.J. 253 (2013).

158. This approach and objective broadly align with other recent efforts to reconcile gaps in antitrust law with developments in economic thinking. See, e.g., C. Scott Hemphill \& Philip J. Weiser, Beyond Brooke Group: Bringing Reality to the Law of Predatory Pricing, 127 YALE L.J. 2048 (2018) (demonstrating the limits of extant predatory pricing law, and showing points of flexibility within the current framework); Hovenkamp \& Shapiro, supra note 16 (defending on economic grounds, and proposing some ways to strengthen the use of structural presumptions in merger review). 


\section{CONCLUSION}

Though it may appear modest in relation to other contemporary antitrust reform proposals, this article shows how the reintroduction of entrenchment theories into modern antitrust could significantly change the enforcement landscape. The entrenchment approach provides a strategy, already accepted in existing caselaw, for addressing the exercise of market power in areas where it is essentially beyond the reach of antitrust today. I have discussed tacit collusion and the exploitation of durable monopoly power as two examples where entrenchment theories could address current concerns, but there is no reason to think that the strategy is limited to these examples. Potential applications include problematic competitive structures in everything from traditional manufacturing, to high technology, to hospitals and healthcare. With that said, the reintroduction of a long dormant enforcement theory would not come free of issues to consider and complexities to unwind. I do not pretend to address all these details in this brief article. I do, however, hope that I have adequately demonstrated the potential of an entrenchment approach for merger enforcement, and that the adoption of this approach may lead to a mature enforcement strategy in years to come. 